\title{
Gambaran kadar albumin serum pada pasien penyakit ginjal kronik stadium 5 non dialisis
}

\author{
${ }^{1}$ Tiffany D. Putri \\ ${ }^{2}$ Arthur E. Mongan \\ ${ }^{2}$ Maya F. Memah
}

\author{
${ }^{1}$ Kandidat Skripsi Fakultas Kedokteran Universitas Sam Ratulangi Manado \\ ${ }^{2}$ Bagian Patologi Klink Fakultas Kedokteran Universitas Sam Ratulangi Manado \\ Email: tiffanyputri.12019@yahoo.com
}

\begin{abstract}
Chronic kidney disease is a pathophysiology process with diverse etiology, causing a progressive decline on kidney function, and in most cases ends with kidney failure (stage 5). The low level of albumin serum is an important predictor of the morbidity and mortality, as a low albumin level is indicating the weak immunity and vitality in kidney failure patients. This is caused by an increase on inflammation and deficiency of protein intake. The low level of albumin serum is also a major indicator which can be used to show a person's kidney function. Hypoalbuminemia occurred if blood albumin level is less than 3,5 g/dL. Research objective: To find out the description of albumin serum level on non-dialysis chronic kidney disease patients. Research method: Cross sectional descriptive, to obtain the data of albumin serum on non-dialysis chronic kidney disease patients carried out on December 2015 - January 2016 at two hospitals, which are RSUP. Prof. Dr. R. D. Kandou Manado and Rumah Sakit Advent Manado. The research sample were the blood sample from 35 people suffering a stage five non dialysis chronic kidney disease, which determined by consecutive sampling from nonprobability sampling model. Result: According to the laboratory result, from the 35 patients diagnosed with a stage five non dialysis chronic kidney disease, 16 patients are having a decrease on albumin serum (45.7\%), and 19 patients are having a normal albumin level (54.4\%). None of the samples are having an increase on albumin level. Conclusion: From the research it can be concluded that there are more patients with normal albumin level which is 29 people (54.5\%) compared to the patients with hypoalbuminemia which is 16 people (45.7\%), with male having a higher tendency of prevalence compared to female on each category of albumin serum checkup.
\end{abstract}

Keywords: albumin serum, stage five chronic kidney disease, non-dialysis.

\begin{abstract}
Abstrak: Penyakit ginjal kronik adalah suatu proses patofisiologi dengan etiologi yang beragam, mengakibatkan penurunan fungsi ginjal yang progresif, dan pada umumnya berakhir dengan gagal ginjal (stadium 5). Kadar serum albumin rendah merupakan prediktor penting dari mordibitas dan mortalitas karena rendahnya serum albumin pada pasien gagal ginjal menggambarkan rendahnya ketahanan dan daya hidup pasien gagal ginjal terminal. Hal ini disebabkan adanya peningkatan inflamasi dan kekurangan asupan protein pada penderita. Rendahnya serum albumin juga salah satu penanda penting yang dapat digunakan untuk menunjukan fungsi ginjal dari seseorang. Dikatakan hipoalbuminemia jika kadar albumin darah kurang dari 3,5 g/dL. Tujuan Penelitian: untuk mengetahui gambaran kadar albumin serum pada pasien penyakit ginjal kronik stadium 5 non dialisis. Metode Penelitan: deskriptif cross sectional, untuk mendapatkan data tentang kadar albumin serum pada pasien penyakit ginjal kronik stadium 5 non dialisis yang dilakukan sejak Desember 2015-Januari 2016 di dua rumah sakit yaitu RSUP. Prof. Dr. R. D. Kandou Manado dan Rumah Sakit Advent Manado. Sampel penelitian adalah sampel darah dari 35 orang yang menderita penyakit ginjal kronik stadium 5 non dialisis ditentukan dengan cara non-probability sampling jenis consecutive
\end{abstract}


sampling. Hasil: Berdasarkan hasil pemeriksaan laboratorium yang dilakukan, terdapat 35 pasien yang terdiagnosis penyakit ginjal kronik stadium 5 non dialisis didapatkan bahwa 16 pasien mengalami penurunan kadar albumin serum (45.7\%), 19 orang memiliki kadar albumin dalam batas normal (54.3\%) dan tidak terdapat peningkatan kadar albumin sama sekali pada pasien yang dilakukan penelitian. Simpulan: Dari hasil penelitian dapat disimpulkan bahwa kadar albumin serum pada pasien dengan kadar albumin yang masih dalam batas normal yaitu sebanyak 19 orang (54.3\%) lebih banyak dibandingkan dengan hipoalbuminemia yaitu sebanyak 16 orang (45.7\%) dimana jenis kelamin laki-laki cenderung lebih tinggi prevalensinya dibandingkan dengan perempuan pada tiap kategori hasil pemeriksaan kadar albumin serum.

Kata kunci: albumin serum, penyakit ginjal kronik stadium 5, non dialisis.

Penyakit ginjal kronik telah menjadi suatu masalah kesehatan utama masyarakat dunia. ${ }^{1}$ Penyakit ginjal kronik adalah suatu proses patofisiologis dengan etiologi yang beragam, mengakibatkan penurunan fungsi ginjal yang progresif, dan pada umumnya berakhir dengan gagal ginjal. ${ }^{2}$ Penyakit ginjal kronik semakin meningkat setiap tahun. Hal tersebut dipengaruhi oleh faktor pertumbuhan, peningkatan proses penuaan, obesitas, dan gaya hidup tidak sehat. ${ }^{3}$

Prevalensi penyakit ginjal kronik yang diperkirakan tahun 2025 di Asia Tenggara, Mediterania dan Timur tengah serta Afrika akan mencapai lebih dari 380 juta orang. ${ }^{2}$ Indonesia termasuk negara dengan tingkat penderita gagal ginjal yang cukup tinggi. Hasil survei yang dilakukan oleh Perhimpunan Nefrologi Indonesia (Pernefri) diperkirakan ada sekitar 12,5\% dari populasi atau sebesar 25 juta penduduk mengalami penurunan fungsi ginjal. ${ }^{3} \mathrm{Di}$ Sulawesi Utara sendiri penyakit ginjal kronis merupakan salah satu penyakit yang sangat beresiko dan menempati urutan ke-4 tertinggi dari 33 provinsi dengan prevalensi 0,4\% pada tahun 2013 . $^{4}$

Pada penyakit ginjal kronik kehilangan protein melalui urin dapat menyebabkan terjadinya penurunan kadar albumin serum atau hipoalbuminemia. Dimana keluarnya albumin melalui urin adalah karena peningkatan permeabilitas di tingkat glomerulus yang menyebabkan protein lolos ke dalam filtrat glomerulus. ${ }^{5}$

Kadar serum albumin rendah merupakan prediktor penting dari mordibitas dan mortalitas. Setiap penurunan $10 \mathrm{~g} / \mathrm{L}$ serum albumin, angka kematian meningkat sebesar $137 \%$ dan morbiditas meningkat 89\%. ${ }^{6}$ Di Indonesia, data hospital malnutrition menunjukkan 40$50 \%$ pasien mengalami hipoalbuminemia atau berisiko hipoalbuminemia, 12\% diantaranya hipoalbuminemia berat, serta masa rawat inap pasien dengan hospital malnutrition menunjukkan 90\% lebih lama daripada pasien dengan gizi baik. ${ }^{7}$ Dikatakan hipoalbuminemia jika kadar albumin darah kurang dari 3,5 g/dL. 6,7

Albumin (69 kDa) merupakan protein utama dalam plasma manusia (3,4-4,7 $\mathrm{g} / \mathrm{dL}$ ), dan membentuk sekitar $60 \%$ protein plasma total. Sekitar $40 \%$ albumin terdapat dalam plasma, dan $60 \%$ sisanya terdapat di ruang ekstrasel. ${ }^{8}$ Albumin berperan dalam membantu mempertahankan tekanan osmotik koloid darah (75-80\% tekanan osmotik plasma), sebagai protein transpor dari beberapa macam substansi antara lain metal, bilirubin, enzim, hormon, obatobatan. $^{9}$

Dalam penelitian ini, penulis mengambil sampel pada penderita gagal ginjal kronik karena rendahnya albumin serum merupakan salah satu tanda penting yang dapat digunakan untuk menunjukkan fungsi ginjal dari seseorang serta menggambarkan rendahnya ketahanan dan daya hidup pasien gagal ginjal terminal. ${ }^{10}$

Penelitian ini bertujuan untuk mengetahui bagaimana gambaran kadar albumin serum pada pasien penyakit ginjal kronik stadium 5 non dialisis. 


\section{METODE PENELITIAN}

Penelitian ini merupakan studi deskriptif cross sectional. Penelitian dilaksanakan di dua rumah sakit yaitu Poliklinik Nefrologi-Hipertensi dan rawat inap bagian Penyakit Dalam RSUP. Prof. Dr. R. D. Kandou Manado dan Rumah Sakit Advent Manado selama bulan Desember 2015 sampai Januari 2016. Sampel penelitian adalah sampel darah dari 35 orang yang menderita penyakit ginjal kronik stadium 5 sesuai criteria yang telah ditentukan dengan cara non-probability sampling jenis consecutive sampling.

\section{HASIL PENELITIAN}

Tabel 1. Distribusi PGK Stadium 5 Non Dialisis Menurut Usia

\begin{tabular}{ccc}
\hline Usia & Jumlah & $\%$ \\
\hline 26-35 Tahun & 1 & $2,86 \%$ \\
36-45 Tahun & 2 & $5,71 \%$ \\
46-55 Tahun & 8 & $22,86 \%$ \\
56-65 Tahun & 7 & $20 \%$ \\
66-75 Tahun & 13 & $37,14 \%$ \\
>75 Tahun & 4 & $11,43 \%$ \\
\hline Jumlah & $\mathbf{3 5}$ & $\mathbf{1 0 0 \%}$ \\
\hline
\end{tabular}

Tabel 2. Distribusi Pasien PGK Stadium 5 Non Dialisis Menurut Jenis Kelamin

\begin{tabular}{ccc}
\hline $\begin{array}{c}\text { Jenis } \\
\text { kelamin }\end{array}$ & Jumlah & $\%$ \\
\hline Laki-laki & 21 & $60 \%$ \\
Perempuan & 14 & $40 \%$ \\
\hline Total & 35 & $100 \%$ \\
\hline
\end{tabular}

Tabel 3. Distribusi pasien PGK stadium 5 non dialisis menurut riwayat penyakit dahulu

\begin{tabular}{ccc}
\hline $\begin{array}{c}\text { Riwayat } \\
\text { penyakit dahulu }\end{array}$ & Jumlah & $\%$ \\
\hline Hipertensi & 29 & $83 \%$ \\
Diabetes melitus & 8 & $23 \%$ \\
Asam urat & 15 & $43 \%$ \\
\hline
\end{tabular}

Tabel 4. Distribusi PGK stadium 5 non dialisis menurut hasil pemeriksaan albumin

\begin{tabular}{ccc}
\hline \multirow{2}{*}{ Nilai } & \multicolumn{2}{c}{ Frekuensi } \\
\cline { 2 - 3 } & Jumlah & \% \\
\hline $\begin{array}{c}\text { Hipoalbumin }(<3.5 \\
\text { g/dL) }\end{array}$ & 16 & $45.7 \%$ \\
$\begin{array}{c}\text { Normal (3.5-5.2 } \\
\text { g/dL) }\end{array}$ & 19 & $54.3 \%$ \\
$\begin{array}{c}\text { Hiperalbumin (>5.2 } \\
\text { g/dL) }\end{array}$ & 0 & $0.0 \%$ \\
\hline \multicolumn{1}{c}{ Total } & $\mathbf{3 5}$ & $\mathbf{1 0 0 \%}$ \\
\hline
\end{tabular}

Tabel 5. Distribusi hasil pemeriksaan kreatinin pasien PGK stadium 5 non dialisis berdasarkan jenis pelayanan medis

\begin{tabular}{ccc}
\hline \multirow{2}{*}{ Pelayanan medis } & \multicolumn{2}{c}{ Jumlah pasien } \\
\cline { 2 - 3 } & $\begin{array}{c}\text { Rawat } \\
\text { jalan }\end{array}$ & $\begin{array}{c}\text { Rawat } \\
\text { inap }\end{array}$ \\
\hline Hipoalbumin & 7 & 7 \\
Normal & 10 & 11 \\
\hline Total & $\mathbf{1 7}$ & $\mathbf{1 8}$ \\
\hline
\end{tabular}

\section{BAHASAN}

Sesuai dengan hasil penelitian di Poliklinik Nefrologi-Hipertensi dan rawat inap bagian Penyakit Dalam RSUP. Prof. Dr. R. D. Kandou Manado dan Rumah Sakit Advent Manado yang dilaksanakan pada bulan Desember 2015-Januari 2016 terdapat 35 penderita penyakit ginjal kronik stadium 5 non dialisis yang telah dikonfirmasi dengan pemeriksaan gejala klinis maupun pemeriksaan penunjang dan telah memenuhi kriteria inklusi.

Berdasarkan data yang diperoleh Tabel 1 , bahwa terdapat 1 orang (2,86\%) pada kelompok usia 26-35 tahun, 2 orang (5,71\%) pada kelompok usia 36-45 tahun, 8 orang pada kelompok usia 46-55 tahun (22,86\%), 7 orang pada kelompok 56-65 tahun (20\%), 13 orang pada kelompok usia 66-75 tahun $(37,14 \%)$, dan 4 orang di atas 75 tahun (11,43\%). Berdasarkan pembagian ini tentu dapat dilihat bahwa kelompok usia 66-75 tahun merupakan kelompok usia terbanyak yang menderita penyakit ginjal kronik stadium 5 non dialisis. Hasil ini hampir sama dengan data statistik National Health and Nutrition Examination Survey Study (NHANES) 
yang menunjukkan bahwa kelompok umur mulai dari 65 tahun atau lebih (24.5\%) merupakan kelompok usia terbanyak yang menderita penyakit ginjal kronik stadium 5 non dialisis. ${ }^{11}$ Namun ada juga hasil penelitian yang berbeda menurut data statistik United States Renal Data System Annual Data Report (USRDS) yang menunjukkan bahwa kelompok umur 45-64 tahun (45\%) merupakan kelompok usia terbanyak yang menderita penyakit ginjal kronik stadium 5 non dialisis. ${ }^{12}$

Berdasarkan data yang diperoleh Tabel 2, terdapat 21 orang laki-laki (60\%) dan 14 orang perempuan (40\%). Hasil ini sama dengan data statistik Screening and Early Evaluation of Kidney Disease study yang menunjukkan bahwa pasien laki-laki (61\%) lebih banyak dari perempuan (39\%). ${ }^{13}$ Hasil tersebut juga sama seperti penelitian yang dilakukan oleh Pranandari $\mathrm{dkk}^{14} \mathrm{di}$ RSUD Wates Kulon Progo Yogyakarta menunjukkan perbandingan antara jumlah laki-laki dan perempuan saat itu adalah sebanyak 2 : 1 .

Berdasarkan Tabel 3, terlihat dari 35 pasien yang terdiagnosis PGK stadium 5 non dialisis, terdapat 29 orang dengan riwayat hipertensi (83\%), 8 orang dengan riwayat diabetes melitus (23\%), 15 orang dengan riwayat asam urat (43\%). Hasil ini berbeda dengan penelitian yang dilakukan oleh Pranandari $\mathrm{dkk}^{14}$ yang mengatakan bahwa pasien dengan riwayat penyakit diabetes mellitus mempunyai resiko terhadap kejadian gagal ginjal kronik 4,1 kali lebih besar dibandingkan dengan penyakit yang lainnya. Namun hasil ini sesuai dengan hasil penelitian yang dilakukan oleh Tjekyan di RSUP Dr. Mohammad Hoesin Palembang yang menunjukkan bahwa faktor risiko terbanyak pada PGK adalah riwayat hipertensi yaitu 126 kasus $(68,9 \%)^{15}$.

Pada hasil pemeriksaan laboratorium Tabel 4, yang dilakukan dapat dilihat bahwa dari 35 pasien yang terdiagnosis penyakit ginjal kronik stadium 5 non dialisis 16 orang mengalami hipoalbuminemia (45,7\%), 19 orang diantaranya memiliki kadar albumin serum yang normal $(54,3 \%)$, dan tidak terdapat satu pun pasien yang mengalami hiperalbuminemia. Hasil ini berbeda dengan teori yang ada bahwa seharusnya pada penyakit ginjal kronik stadium 5 terdapat hipoalbuminemia atau penurunan kadar albumin di dalam darah dimana konsentrasi albumin plasma ditentukan oleh asupan protein, sintesis albumin hati, dan kehilangan protein melalui urin. Hipoalbuminemia juga dikaitkan dengan mortalitas pada pasien dengan stadium akhir penyakit ginjal. Namun menurut hasil penelitian yang dilakukan oleh Zuyana L $\mathrm{dkk}^{16}$ dimana kadar albumin serum normal juga dapat terjadi dari adanya kemungkinan intervensi yang telah dilakukan sebelumnya, baik berupa diet, adanya asupan mengandung protein atau obatobatan yang dapat mempengaruhi kondisi subjek penelitian.

Pada Tabel 5, dapat dilihat dari 35 pasien PGK stadium 5 non dialisis, terdapat 17 pasien rawat jalan dan 18 pasien rawat inap. Jumlah pasien rawat jalan yang mengalami hipoalbumin yaitu 7 orang, dan terdapat 10 orang dengan kadar albumin normal. Sedangkan jumlah pasien rawat inap yang mengalami hipoalbumin yaitu 7 orang, dan terdapat 11 orang pasien dengan kadar albumin normal. Hasil tersebut menunjukkan bahwa pada pasien rawat jalan dengan kadar albumin serum normal lebih banyak dibandngkan hipoalbumin. kadar albumin serum normal ini dapat terjadi dari adanya kemungkinan intervensi yang telah dilakukan sebelumnya, baik berupa diet, adanya asupan mengandung protein atau obat-obatan yang dapat mempengaruhi subjek penelitian. Dan pada pasien rawat inap lebih banyak yang memiliki kadar normal dibandingkan hipoalbumin. ini dikarenakan penangan yang sudah dilakukan pada pasien rawat inap berupa pemberian infus intravena yang juga mengangung protein sehingga membuat hasil pemeriksaan normal.

Kelemahan dari penelitian ini adalah tidak melihat faktor-faktor yang mempengaruhi sebab dan akibat, tidak diketahui insidensi yang diteliti terjadi 
sebelum atau sesudah terpajan penyakit yang diderita, sehingga sulit melakukan perbandingan dan tidak dapat melihat perubahan yang terjadi dengan berjalannya waktu serta keterbatasan waktu.

\section{SIMPULAN}

Berdasarkan hasil penelitian ini maka dapat disimpulkan bahwa:

1. Jumlah pasien PGK stadium 5 non dialisis yang diperoleh dari RSUP Prof Dr. R.D Kandou Manado dan RS Advent Teling adalah 35 pasien diantaranya terdiri dari 21 orang lakilaki $(60,0 \%)$ dan 14 orang perempuan (40,0\%).

2. Pasien dengan kadar albumin yang masih dalam batas normal yaitu sebanyak 19 orang (54.3\%) lebih banyak dibandingkan dengan hipoalbuminemia yaitu sebanyak 16 orang $(45.7 \%)$ dimana jenis kelamin laki-laki cenderung lebih tinggi prevalensinya dibandingkan dengan perempuan pada tiap kategori hasil pemeriksaan kadar albumin serum.

\section{DAFTAR PUSTAKA}

1. Davidson SN. Chronic kidney disease psychosocial impact of chronic pain. Psychiatric consultant. 2007;62:2.17

2. Suwitra K. Penyakit ginjal kronik. Dalam Sudoyo Aru W, Setiyohadi Bambang, Alwi Idrus. Editors: Buku Ajar Ilmu Penyakit Dalam. Jilis II, Edisi V. Jakarta. Interna publishing;2009.h.1035

3. Nurchayati S. Faktor-faktor yang berhubungan dengan kualitas hidup pasien penyakit ginjal kronik hemodialisis di RS Islam Fatimah Cilacap dan RSUD Banyumas. [Tesis]. [Depok]: Universitas Indonesia; 2010

4. Sumigar G, Rompas S, Pondaag $L$. Hubungan dukungan keluarga dengan kepatuhan diet pada pasien gagal ginjal kronik di irina C2 dan C4 RSUP Prof. Dr. R. D. Kandou Manado. 2015;3:2.

5. Lin J. Proteinuria in chronic kidney disease. Chronic kidney disease. 6th ed. Los Angeles: Henry Ford Health System; 2011.p.24-25.
6. Peralta R. Hypoalbuminemia. 2015 Apr 1. Available from: http://emedicine.medscape.com/article/ 166724

7. Rachnindar D. Hypoalbuminemia. 2013 Feb 9. Available from: http://id.scribd.com/doc/124643683/Hy poalbuminemia

8. Murray RK, Granner DK, Rodwell VW. Protein plasma dan imunoglobulin. Dalam: Buku ajar Biokimia harper. Edisi 27. Jakarta: EGC;2009.h.608.

9. Lee JS. Albumin for End-Stage Liver Disease. Journal of the korean association of internal medicine. 2012;27:1.p.14.

10. Kilates MC. Nutrition in chronic kidney disease. Chronic kidney disease. 6th ed. Los Angeles: Henry Ford Health System; 2011.p.43-44.

11. Kidney disease statistics of United States. Journal of the national institute of health.2010.p.2.

12. Nicola L, Minutolo R, Chiodini $P$, Borrelli S, Zoccali C, Postorino M, dkk. The effect of increasing age on the prognosis of non-dialysis patients with chronic kidney disease receiving stable nephrology care. National Kidney Foundation Journal. 2012;82:482-8.

13.Singh A, Farag M, Mittal B, Subramanian K, Reddy S, Acharya V. Epidemiology and risk factors of chronic kidney disease in India: results from the Screening and Early Evaluation of Kidney Disease study. 2013 May 28. Available from: http://bmcnephrol.biomedcentral.com/a rticles.

14.Pranandari R, Supadmi W. Risk factors chronic renal failure on hemodialysis unit in RSUD wates kulon progo. Journal of Ahmad Dahlan University. 2015;11:2.p.318.

15. Suryadi RM. Prevalensi dan Faktor Risiko Penyakit Ginjal Kronik di RSUP Dr. Mohammad Hoesin Palembang Tahun 2012. Jurnal Fakultas Kedokteran Universitas Sriwijaya. 2014:277.

16.Zuyana L, Adriani M. Perbedaan Asupan Makan dan Status Gizi antara Pasien Hemodialisis Adekuat dan Inadekuat Penyakit Ginjal Kronik. Jurnal Fakultas Kesehatan Masyarakat Universitas Airlangga. 2013:15-16. 